\title{
Beech Wood Thermally Modified in the Melt of Polyethylene Glycol
}

\author{
Ladislav Reinprecht* and Miroslav Repák
}

\begin{abstract}
Various techniques of wood thermal modification in air, liquids, or melts at temperatures above $160^{\circ} \mathrm{C}$ improve its resistance to biological damage and water. In this experiment, the European beech (Fagus sylvatica L.) wood was held for 1 to 4 hours in the melt of polyethylene glycol 6000 (PEG 6000) and during a given time either heated at $100^{\circ} \mathrm{C}$ or thermally modified at 190 or $210^{\circ} \mathrm{C}$. Its decay resistance improved - maximally at using the more intense modification mode $210{ }^{\circ} \mathrm{C} / 4 \mathrm{~h}$ - to Poria placenta by $60.3 \%$ and to Trametes versicolor by $62.8 \%$. The soaking and volume swelling in water of the PEG-thermally treated beech wood usually was significantly reduced, after $336 \mathrm{~h}$ maximally by $60 \%$ and $34.6 \%$, respectively. The presence of PEG during the thermal modification processes caused darkening of beech wood - a decoratively interesting and more pronounced effect than what occurs in traditional air-thermal modifications - at which the $\Delta E_{a b}{ }^{*}$ was also great from 13.1 to 52.6. However, since the mechanical properties of the PEG-thermally modified beech wood worsened - impact bending strength maximally by $34 \%$ and Brinell hardness maximally by $43.3 \%$ - its application for structural elements would be limited.
\end{abstract}

DOI: 10.15376/biores.17.1.652-672

Keywords: Beech wood; Polyethylene glycol; Thermal modification; Decaying fungi; Swelling; Mechanical properties

Contact information: Technical University in Zvolen, Faculty of Wood Sciences and Technology, Department of Wood Technology, T. G. Masaryka 24, SK-960 01 Zvolen, Slovak Republic;

*Corresponding author: reinprecht@tuzvo.sk

\section{INTRODUCTION}

European beech (Fagus sylvatica L.) wood is often utilized for furniture, building, transportation, and other products. This wood species is easily workable and impregnable; however, its dimensional stability at climatic changes is not sufficient and its durability to decaying fungi and wood-boring insects is poor according to EN 350 (2016) standard requirements. Some of its worse properties can be improved by the thermal, chemical, or thermal-chemical modification processes (Sandberg et al. 2021).

Thermal modification of wood is performed usually in the absence or with a reduced content of oxygen, using high temperatures from 160 to $260{ }^{\circ} \mathrm{C}$, with the aim to make specific changes in its molecular structure and to improve its selected properties mainly its resistance to water and biotic agents (Hill 2006; Esteves and Pereira 2009; Yilgör and Kartal 2010; Tümen et al. 2010; Sandberg et al. 2021). Changes in wood structure are associated primarily with deacetylation and degradation of hemicelluloses, creation of hemicelluloses-lignin linkages, cleavage of ether linkages in lignin, secession of hydroxyl and methoxyl groups, and creation of more condensed structures (Tjeerdsma et al. 1998; 
Wikberg and Maunu 2004; Reinprecht and Vidholdová 2011; Cai et al. 2018). The types and extents of changes in the molecular structure of thermally modified wood and subsequently in its specific properties depend not only on the height and duration of temperature action, but also on the wood species, its initial moisture content, as well as on parameters of the heating medium, i.e., of the air, nitrogen, steam pressure, plant oils, waxes, etc. (Hill 2006; Kocaefe et al. 2015; Reinprecht 2016; Sandberg et al. 2021).

Biological resistance of the thermally modified wood increases due to application higher temperatures, usually from 160 to $220^{\circ} \mathrm{C}$ or in the absence of oxygen also up to 260 ${ }^{\circ} \mathrm{C}$ (Rapp and Sailer 2001; Reinprecht et al. 2007; Yilgör and Kartal 2010; Westin et al. 2013). In comparison to the most common thermal modification process in hot air, a higher resistance of wood to moulds, decaying fungi, and water is ensured when its heating is performed in hot plant oils, melt waxes, or some other liquid substances (Rapp and Sailer 2001; Wang and Cooper 2005; Reinprecht et al. 2007; Hasan et al. 2008; Reinprecht and Vidholdová 2008; Dubey et al. 2012; Reinprecht and Repák 2019). For example, non-toxic and environmentally acceptable hydrophobic paraffin and various waxes decrease the water absorption rate of wood (Reinprecht and Repák 2019), improve its dimensional stability (Scholz et al. 2009), and also improve its resistance to termites (Scholz et al. 2010; Esteves et al. 2014). On contrary, deteriorated are mechanical properties of thermally modified woods, mainly their strength and less significantly their modulus of elasticity (Hill 2006; Sandberg et al. 2021).

Polyethylene glycols (PEGs) are hydrophilic, polar macromolecules. At room temperature they are either liquids (lower molecular weight, e.g., PEG 300 up to PEG 1000) or solids with a wax consistency (higher molecular weight, e.g., PEG 1500 up to PEG 10000). In practice, various PEG types are successfully used for a dimensional stabilization of archaeological waterlogged wooden artefacts (Unger et al. 2001; Hocker et al. 2012; Majka et al. 2018). However, polar and lower molecular PEGs usually decrease all strength properties of dried wood, because wood treated with them has permanently swollen cell walls, and the natural strengthening effect of hydrogen bonds inside the cell walls consisting from polysaccharide and lignin molecules is suppressed (Almkvist et al. 2016). PEG-thermal techniques could also be used for conservation of moist archaeological wooden artefacts. The best effects can be obtained with a mixture of: (a) the lower molecular weight PEGs 300 - 600 able to penetrate to lumina of wood cells and following also to the inside of cell walls gradually dewatered at increased temperatures, and (b) the higher molecular weight PEGs 2000 - 6000 able to penetrate to lumina and partly also into damaged/perforated cell walls.

The aim of this work was to determine the effect of thermal modification of the European beech wood in the melt of higher molecular weight PEG 6000 to increase its resistance to rot and water, and at the same time to evaluate the PEG-thermal modification process on the wood color and its selected mechanical properties. The basic advantage of such technique could be, for example, a combined chemical-thermal modification of specific wood products exposed to moderately moist environment - including archaeological artefacts for outdoor exposition under the shelter. 


\section{EXPERIMENTAL}

\section{Wood and PEG}

Experiments were performed with European beech (Fagus sylvatica L.) wood specimens of four dimensional types (Fig. 1): (a) $25 \mathrm{~mm} \times 25 \mathrm{~mm} \times 5 \mathrm{~mm}$ (longitudinal $\times$ tangential $\times$ radial) for testing the decay resistance and Brinell hardness; (b) $5 \mathrm{~mm} \times 50 \mathrm{~mm} \times 25 \mathrm{~mm}$ (longitudinal $\times$ tangential $\times$ radial) for testing the soaking and swelling; (c) $50 \mathrm{~mm} \times 50 \mathrm{~mm} \times 10 \mathrm{~mm}$ (longitudinal $\times$ tangential $\times$ radial) for testing the color and its changes on four defined places spaced $15 \mathrm{~mm}$ from the edges of the specimen; and (d) $120 \mathrm{~mm} \times 10 \mathrm{~mm} \times 10 \mathrm{~mm}$ (longitudinal $\times$ tangential $\times$ radial) for testing the impact bending strength. Beech wood specimens were prepared from sawn timbers stored in the National Forest Centrum in Zvolen and naturally seasoned to a moisture content of $13.5 \pm 2 \%$.

The following numbers of specimens were used: (a) type -96 thermally treated and 48 reference specimens for attack by the wood-decaying fungi, as well as 72 thermally treated and 6 reference specimens for testing the Brinell hardness; (b) type -72 thermally treated and 6 reference specimens for testing the soaking and swelling; (c) type -24 thermally treated and 2 reference specimens for testing the color, always on four defined places of each specimen; and (d) type -72 thermally treated and 6 reference specimens for testing the impact bending strength.

Specimens selected for experiments contained only heart-wood, and their quality was high, i.e., they did not have rot, insect galleries, growth defects, tension, or red-false wood, at which their top and bottom surfaces were milled. Initial mass of specimens with an accuracy of $0.001 \mathrm{~g}$ was determined in the oven-dry state, after drying at $103 \pm 1{ }^{\circ} \mathrm{C}$ and subsequent cooling in desiccators to a temperature of $20 \pm 2{ }^{\circ} \mathrm{C}$.

a)
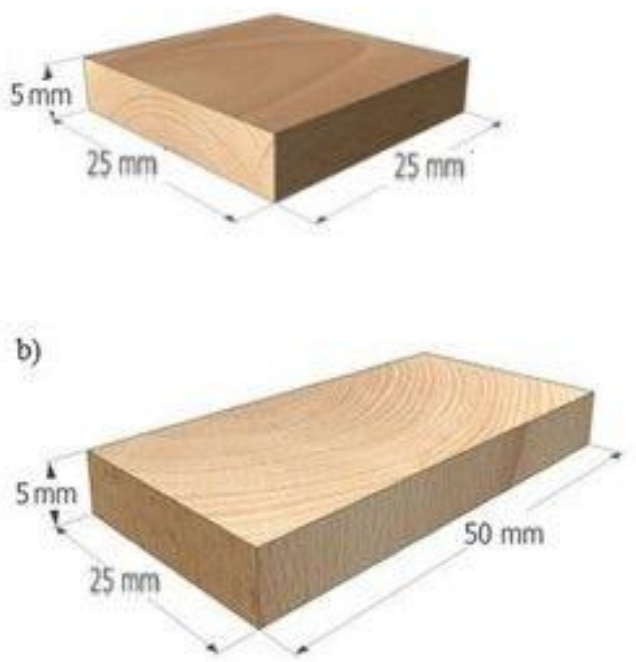

c)
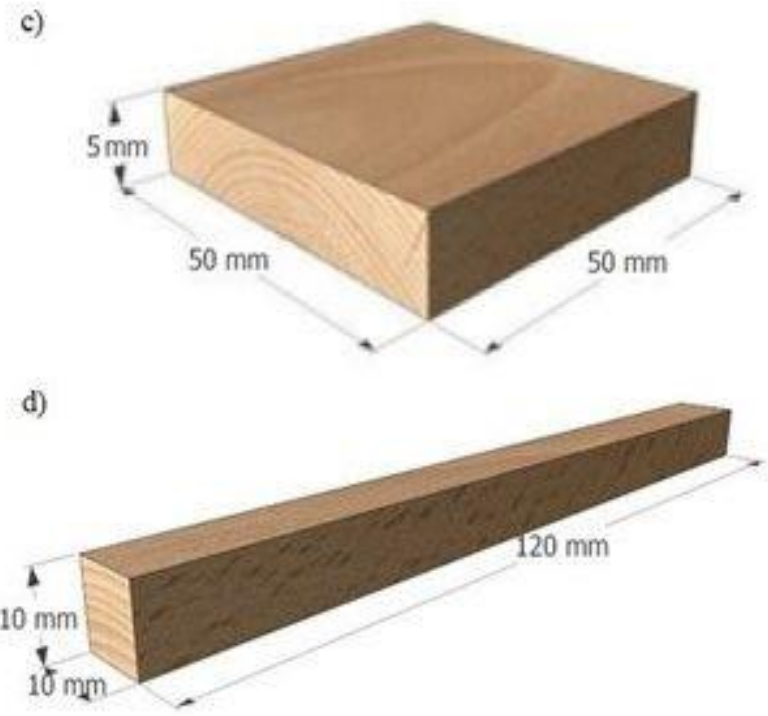

Fig. 1. Types of beech wood specimens for the PEG heating and PEG-thermal modification

Polyethylene glycol 6000 (PEG 6000) (HiMedia, Laboratories Pvt. Ltd., Mumbia, India), with a melting point of $58 \pm 3{ }^{\circ} \mathrm{C}$ and a molecular weight from 5000 to $7000 \mathrm{~g} / \mathrm{mole}$ was used as the melt-liquid medium for the heating at $100{ }^{\circ} \mathrm{C}$ and thermal modification at 190 and $210{ }^{\circ} \mathrm{C}$ of beech wood specimens. 


\section{PEG-thermal Treatment of Beech Wood}

The PEG-thermal treatments, i.e., heating and modification, of beech wood specimens in the melt of PEG 6000 were performed by the soaking method in the Memmert UNB 100 kiln (Memmert GmbH + Co.KG, Schwabach, Germany). In the first phase, the solid PEG 6000 was melted in stainless steel containers when its temperature increased to $100{ }^{\circ} \mathrm{C}$ during the first $1 \mathrm{~h}$. In the second phase, the wood specimens were inserted into the melted PEG 6000 and were impregnated at atmospheric pressure and a temperature of 100 ${ }^{\circ} \mathrm{C}$ during $1 \mathrm{~h}$. In the third phase, lasting $1 \mathrm{~h}$, the temperature of the PEG 6000 melt was either stable $100{ }^{\circ} \mathrm{C}$ or it increased continuously to 190 and $210{ }^{\circ} \mathrm{C}$. In the fourth phase, the temperature of the PEG 6000 was maintained at 100,190 , or $210{ }^{\circ} \mathrm{C}$ for $1,2,3$, or $4 \mathrm{~h}$. In the fifth phase, i.e., the last phase, the modified beech wood specimens were cooled approximately to $75{ }^{\circ} \mathrm{C}$, then taken out from steel containers and their surfaces cleaned from the PEG 6000 liquid-melt with filter papers, and finally cooled in desiccators to a temperature of $20 \pm 2{ }^{\circ} \mathrm{C}$ (Fig. 2).

The cooled oven-dry PEG-thermally treated beech wood specimens, i.e., with a moisture content of $0 \%$, were weighed with an accuracy of $0.001 \mathrm{~g}$, and their dimensions were measured with an accuracy of $0.01 \mathrm{~mm}$.

The oven-dry specimens were used for the soaking and swelling tests. Specimens exposed to the decay, color, and mechanical tests were first 14 days conditioned to a moisture content of $10 \% \pm 2 \%$ at a temperature of $20 \pm 2{ }^{\circ} \mathrm{C}$ and a relative air humidity of $60 \% \pm 3 \%$.

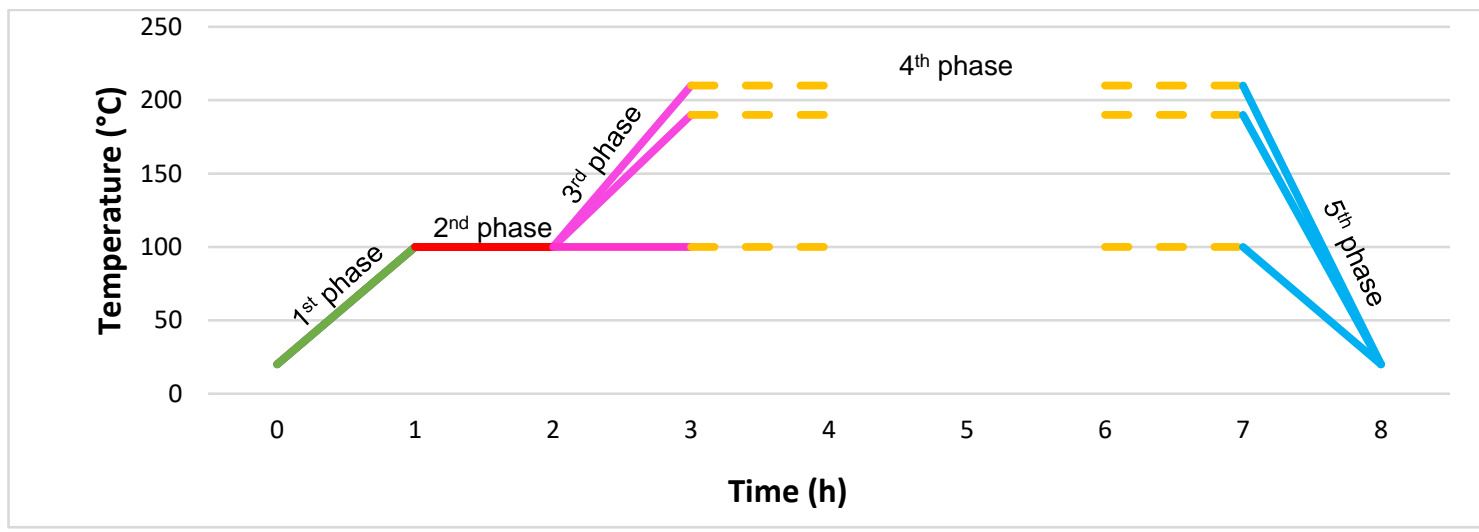

Fig. 2. Schematic representation of individual phases of the PEG-thermal treatments of beech wood specimens. Note: The $4^{\text {th }}$ phase duration ranged from one to four hours.

The weight percent gains (WPG and $W P G^{*}$ ) of PEG 6000 into beech wood specimens were determined separately: (I.) for the "impregnation-heating" process performed at $100{ }^{\circ} \mathrm{C}$ with selected groups of specimens, and (II.) for the "impregnationthermal-modification" processes performed at $190{ }^{\circ} \mathrm{C}$ and $210{ }^{\circ} \mathrm{C}$ with another selected groups of specimens. The $W P G^{*}$ values $\left(W P G^{*}=W P G-\Delta m\right.$ Thermal $)$, so-called "the real $W P G$ values", took into account the "theoretical" weight losses of specimens ( $\Delta$ Thermal $)$ during their thermal modification at 190 or $210{ }^{\circ} \mathrm{C}$ in the $4^{\text {th }}$ phase (Fig. 2).

The $\Delta$ mThermal values, which are connected mainly with a thermal degradation of hemicelluloses in wood, were calculated by Eq. 1,

$$
\Delta m_{\text {Thermal }}=W P G-W P G^{*}(\%)
$$




\section{Resistance to Decaying Fungi}

The reference, PEG-heated, and PEG-thermally modified beech wood specimens with dimensions of $25 \mathrm{~mm} \times 25 \mathrm{~mm} \times 5 \mathrm{~mm}(\mathrm{~L} \times \mathrm{T} \times \mathrm{R})$ were subjected to attack by the brown-rot fungus Poria placenta (Fries) Cooke sensu J. Eriksson, strain FPRL 280 (Building Research Establishment, Garston - Watford, UK) and by the white-rot fungus Trametes versicolor (Linnaeus ex Fries) Pilat, strain BAM 116 (Bundesanstalt für Materialforschung und -prüfung, Berlin, Germany).

Fungal attack of specimens was performed in Petri dishes with a diameter of 100 mm during 6 weeks by a modified standard EN 113 (1996), i.e., in accordance with fungal attacks of the paraffin-thermally treated beech wood specimens (Reinprecht and Repák 2019) and with the rapid mycological screening test by Van Acker et al. (2003).

In the vaccination box (Merci, Ferrara, Italy), two replicates of the equally thermally treated specimen type and one replicate of the reference (thermally untreated without presence of PEG) specimen were placed into Petri dishes. Specimens were placed on plastic mats under which a fungal mycelium was already grown on a sterilized $4.5 \mathrm{wt} \%$ 3-to 4-mm-thick malt agar medium (HiMedia, Laboratories Pvt. Ltd., Mumbai, India). After the fungal attack, the specimens were cleared of fungal mycelia, then air-conditioned for 14 days at a temperature of $20 \pm 2{ }^{\circ} \mathrm{C}$ and a relative air humidity of $60 \pm 3 \%$, and weighed to determine the weight loss $(\Delta m)$ by Eq. 2 ,

$$
\Delta m=\frac{m_{0}-m_{0 \text { deg }}}{m_{0}} \times 100(\%)
$$

where $m_{0}$ is weight of specimen in the conditioned state before mycological test $(\mathrm{g})$ and $m_{0 \text { deg }}$ is weight of specimen in the conditioned state after mycological test (g).

\section{Soaking and Swelling}

The soaking and swelling tests of wood specimens with dimensions of $5 \mathrm{~mm} \times 50$ $\mathrm{mm} \times 25 \mathrm{~mm}(\mathrm{~L} \times \mathrm{T} \times \mathrm{R})$ were performed according to the standard STN 490104 (1987) and evaluated after 24 and 336 h by Eqs. 3 and 4,

$$
\begin{aligned}
& S_{\mathrm{i}}=\frac{m_{\mathrm{i}}-m_{0}}{m_{0}} \times 100(\%) \\
& \beta_{\mathrm{Vi}}=\frac{V_{\mathrm{i}}-V_{0}}{V_{0}} \times 100(\%)
\end{aligned}
$$

where $S_{\mathrm{i}}$ is absorption of distilled water $(\%), m_{\mathrm{i}}$ is mass of the moist specimen at the defined time of soaking $(\mathrm{g}), m_{0}$ is mass of the oven-dry specimen $(\mathrm{g}), \beta_{\mathrm{Vi}}$ is volume swelling of wood $(\%), V_{\mathrm{i}}$ is volume of the moist specimen at the defined time of soaking $\left(\mathrm{mm}^{3}\right)$, and $V_{0}$ is volume of the oven-dry specimen $\left(\mathrm{mm}^{3}\right)$.

\section{Color}

The color parameters of beech wood specimens were determined before and after their PEG-thermal treatments using a colorimeter Colour Reader CR-10 (Konica Minolta, Osaka, Japan). The light source was defined by a standard illuminant D65 with an observer angle of $8^{\circ}$ and sensor head with a diameter of $8 \mathrm{~mm}$. In each series of specimens, eight color measurements were performed, i.e., the color was measured for two specimens from the same series, at which the color on the top surface $50 \mathrm{~mm} \times 50 \mathrm{~mm}(\mathrm{~L} \times \mathrm{T})$ of specimen was determined in four defined places. The total color difference, according to the 
Euclidean distance $\Delta E_{a b} *$ (CIE 2007), was calculated with Eq. 5, using measured $L^{*}, a^{*}$, and $b^{*}$ coordinates,

$$
E_{a b}^{*}=\sqrt{\left(\Delta L^{* 2}+\Delta a^{* 2}+\Delta b^{* 2}\right)}
$$

where $\Delta L^{*}, \Delta a^{*}$, and $\Delta b^{*}$ are relative changes in color after PEG thermal treatments; $L^{*}$ is lightness from 0 (black) to 100 (white), $a^{*}$ is the chromaticity coordinate + (red) or (green), and $b^{*}$ is the chromaticity coordinate + (yellow) or - (blue).

\section{Impact Bending Strength and Brinell Hardness}

The impact bending strength (I) of wood specimens $120 \mathrm{~mm} \times 10 \mathrm{~mm} \times 10 \mathrm{~mm}(\mathrm{~L}$ $\times \mathrm{T} \times \mathrm{R})$ in the tangential direction was determined according to the standard EN ISO 3348 (1975), and calculated using Eq. 6,

$$
I=\frac{W}{b \times h}\left(\mathrm{~J} \cdot \mathrm{cm}^{-2}\right)
$$

where $W$ is the energy needed to break the specimen $(\mathrm{J}), b$ is the width, and $h$ is the height of the specimen $(\mathrm{cm})$.

The Brinell hardness of wood specimens in the radial direction $\left(H_{\mathrm{B}}\right)$ was evaluated according to the standard EN 1534 (2020), using a steel ball with a diameter $(D)$ of 11.284 $\mathrm{mm}$ impressed into the wood surface with a force $(F)$ of $500 \mathrm{~N}$, and calculated by Eq. 7,

$$
H_{\mathrm{B}}=\frac{F}{S}=\frac{2 \times F}{\pi \times D \times\left(D-\sqrt{D^{2}-d^{2}}\right)}(\mathrm{MPa})
$$

where $d$ is diameter of the impressed area in the specimen ( $\mathrm{mm})$.

\section{Statistical Analyses}

The statistical software Statistica 12 (StatSoft, Inc., Tulsa, Oklahoma, USA) was used for analysing the gathered data and the basic statistical characteristics of studied properties were determined, i.e., their arithmetic means and standard deviations. Duncan tests were used to analyse the differences between the modified and reference specimens on the significance levels of: $\mathrm{a} \geq 99.9 \%, \mathrm{~b} \geq 99 \%, \mathrm{c} \geq 95 \%$, or without significance $\mathrm{d}<$ $95 \%$.

\section{RESULTS AND DISCUSSION}

The PEG-thermally modified beech wood specimens acquired increased resistance to wood decaying fungi (Table 1), had lower water absorption and swelling in water (Tables 2 and 3, Figs. 4 and 5), and their color obviously changed (Table 4, Fig. 6); however, their mechanical properties worsened (Table 5).

\section{Thermal-treatment Processes Analyzed by WPG and $\Delta m_{\text {Thermal }}$ values}

The $W P G$ and $W P G^{*}$ values of PEG 6000 into beech wood specimens during heating (at $100{ }^{\circ} \mathrm{C}$ ) and thermal modification (at $190{ }^{\circ} \mathrm{C}$ and $210{ }^{\circ} \mathrm{C}$ ) processes, respectively, are presented in Figs. 3a to $3 \mathrm{c}$. The highest $W P G$ and $W P G^{*}$ values were determined for the smallest specimen type (a) $(25 \mathrm{~mm} \times 25 \mathrm{~mm} \times 5 \mathrm{~mm})$, and for specimen type (b) $(5 \mathrm{~mm} \times 50 \mathrm{~mm} \times 25 \mathrm{~mm})$ having the highest portion of axial areas (Fig. 1 and Figs. $3 \mathrm{a}$ to $3 \mathrm{c}$ ). The $\Delta m_{\text {Thermal }}$ values, which indicate the theoretical weight loss of 
specimens during thermal modifications at 190 and $210^{\circ} \mathrm{C}$, are present in Figs. $3 \mathrm{~d}$ and 3e. It should be emphasised that the $\Delta m_{\text {Thermal }}$ values are only theoretical ones, because they were not calculated from the same group of specimens, but from individual groups of specimens treated at 100,190 , or $210^{\circ} \mathrm{C}$. This means the $W P G$ of specimens treated at 100 ${ }^{\circ} \mathrm{C}$ and $W P G^{*}$ of specimens treated at $190{ }^{\circ} \mathrm{C}$ or $210^{\circ} \mathrm{C}$.

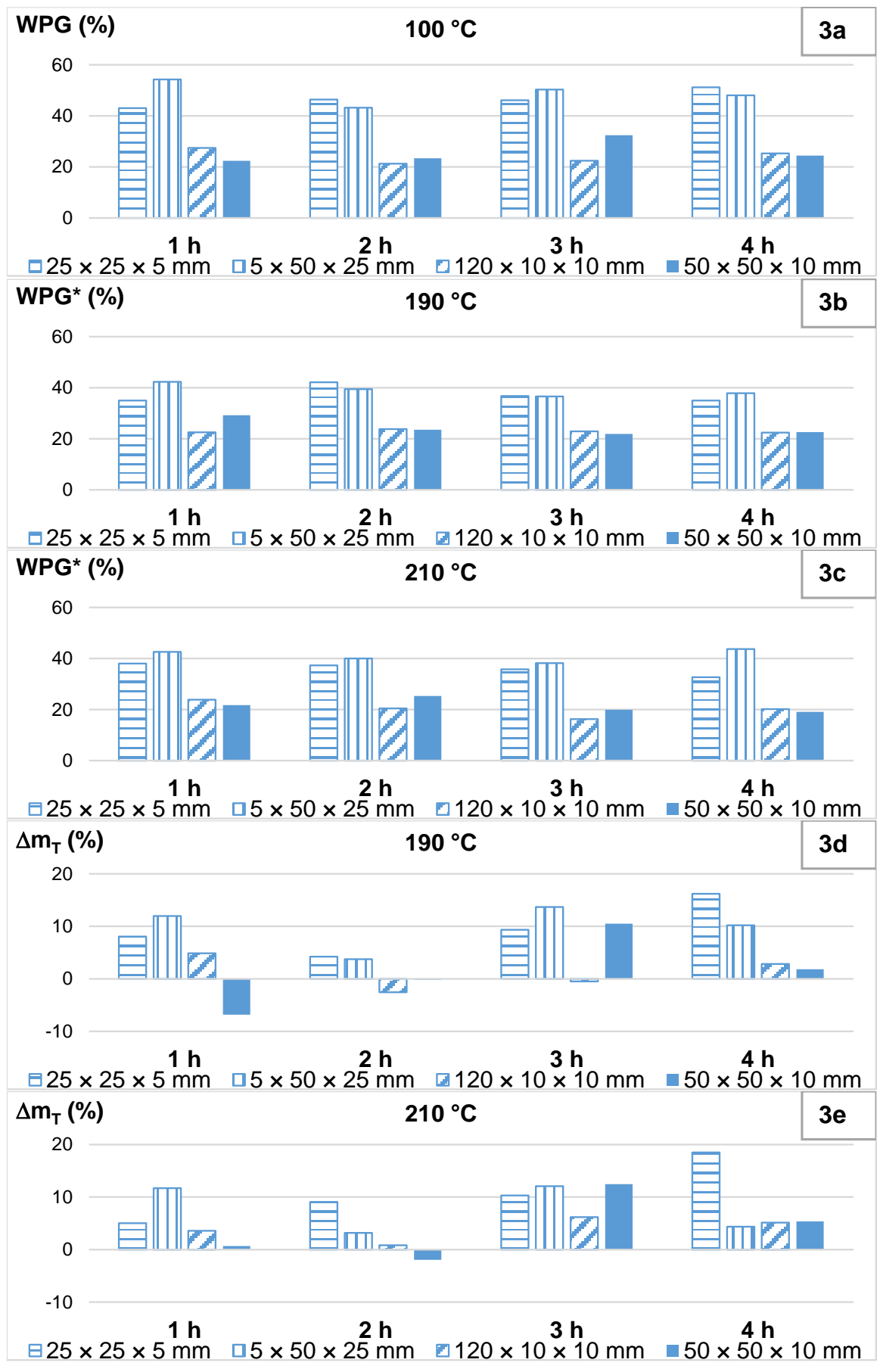

Fig. 3. The WPG values of PEG 6000 for specimens (longitudinal $\times$ tangential $\times$ radial) heated at $100{ }^{\circ} \mathrm{C}(3 \mathrm{a})$, the WPG * values of PEG 6000 for specimens thermally modified at $190^{\circ} \mathrm{C}$ or $210^{\circ} \mathrm{C}$ (3b, 3c), and the indirectly calculated mass losses $\Delta m_{\text {Thermal }}$ of specimens caused during their thermal modification at $190^{\circ} \mathrm{C}$ or $210^{\circ} \mathrm{C}(3 \mathrm{~d}, 3 \mathrm{e})$ 


\section{Resistance of the PEG-Thermally Treated Beech Wood to Decaying Fungi}

Beech wood specimens after all PEG-thermal modification modes, performed at 190 and $210{ }^{\circ} \mathrm{C}$, gained increased resistance to rot (Table 1). The highest weight losses $(\Delta m)$ were observed for the reference specimens - for the brown rot fungus Poria placenta, the $\Delta m$ value was more than $24 \%$, and for to the white-rot fungus Trametes versicolor more than $26 \%$. The rot resistance of beech wood improved the most, on the $99.9 \%$ significance level, at the modification modes $210^{\circ} \mathrm{C} / 3 \mathrm{~h}$ and $210{ }^{\circ} \mathrm{C} / 4 \mathrm{~h}$ - against P. placenta by $47.3 \%$ and $60.3 \%$, respectively, and against $T$. versicolor by $50.9 \%$ and $62.8 \%$, respectively. Rot resistance against $T$. versicolor significantly increased also at the less intense thermal modification mode $190{ }^{\circ} \mathrm{C} / 4 \mathrm{~h}$, by $57.7 \%$.

Table 1. Weight Loss $(\Delta m)$ of the PEG-Heated $\left(100^{\circ} \mathrm{C}\right)$ and PEG-Thermally Modified $\left(190^{\circ} \mathrm{C} ; 210^{\circ} \mathrm{C}\right)$ Beech Wood Specimens Caused by the Decaying Fungi $P$. placenta and $T$. versicolor

\begin{tabular}{|c|c|c|}
\hline $\begin{array}{c}\text { Modes of Beech Wood } \\
\text { Treatment in PEG } 6000\end{array}$ & $\begin{array}{c}\text { Poria placenta } \\
\Delta \boldsymbol{m}(\%)\end{array}$ & $\begin{array}{c}\text { Trametes versicolor } \\
\boldsymbol{\Delta} \boldsymbol{m}(\%)\end{array}$ \\
\hline Reference & $24.48(5.31)$ & $26.57(3.26)$ \\
\hline $100^{\circ} \mathrm{C} / 1 \mathrm{~h}$ & $19.34(3.86) \mathrm{d}$ & $19.12(4.06) \mathrm{c}$ \\
\hline $100^{\circ} \mathrm{C} / 2 \mathrm{~h}$ & $19.98(2.92) \mathrm{d}$ & $22.71(6.64) \mathrm{d}$ \\
\hline $100^{\circ} \mathrm{C} / 3 \mathrm{~h}$ & $23.78(4.83) \mathrm{d}$ & $26.92(3.43) \mathrm{d}$ \\
\hline $100^{\circ} \mathrm{C} / 4 \mathrm{~h}$ & $27.71(2.15) \mathrm{d}$ & $28.40(2.62) \mathrm{d}$ \\
\hline $190^{\circ} \mathrm{C} / 1 \mathrm{~h}$ & $18.63(2.42) \mathrm{d}$ & $25.24(5.71) \mathrm{d}$ \\
\hline $190^{\circ} \mathrm{C} / 2 \mathrm{~h}$ & $17.38(1.14) \mathrm{c}$ & $18.33(4.18) \mathrm{c}$ \\
\hline $190^{\circ} \mathrm{C} / 3 \mathrm{~h}$ & $17.17(1.36) \mathrm{c}$ & $17.99(5.96) \mathrm{c}$ \\
\hline $190^{\circ} \mathrm{C} / 4 \mathrm{~h}$ & $14.30(2.01) \mathrm{b}$ & $11.24(5.42) \mathrm{a}$ \\
\hline $210^{\circ} \mathrm{C} / 1 \mathrm{~h}$ & $19.61(1.30) \mathrm{d}$ & $21.14(2.38) \mathrm{d}$ \\
\hline $210^{\circ} \mathrm{C} / 2 \mathrm{~h}$ & $16.89(1.03) \mathrm{c}$ & $16.16(6.05) \mathrm{b}$ \\
\hline $210^{\circ} \mathrm{C} / 3 \mathrm{~h}$ & $12.90(3.25) \mathrm{a}$ & $13.05(6.36) \mathrm{a}$ \\
\hline $210^{\circ} \mathrm{C} / 4 \mathrm{~h}$ & $9.73(2.61) \mathrm{a}$ & $9.88(2.07) \mathrm{a}$ \\
\hline
\end{tabular}

Note: Average values were determined from 4 test specimens and 24 reference ones. Standard deviations (SD) are in parentheses. The Duncan test was performed in relation to reference samples with significance levels of: $a=99.9 \%, b=99 \%, c=95 \%$ and $d<95 \%$

Pelit and Yalçin (2017) determined a similar anti-decay effect for the densified pine sap-wood due to its following post-thermal treatment at $212{ }^{\circ} \mathrm{C} / 2 \mathrm{~h}$. Weight losses of such treated wood were, after attack by $T$. versicolor, reduced by $73 \%$ and after attack by the brown-rot fungus Coniophora puteana, by $67 \%$. On the contrary, the densification processes by itself did not have significant anti-decay effect.

In this experiment, in contrast to the experiment with the paraffin-thermally modified beech wood (Reinprecht and Repák 2019), the white-rot fungus T. versicolor did not cause higher weight losses of the PEG-thermally modified beech wood than the brownrot fungus $P$. placenta. However, comparing with the paraffin-thermally modified beech wood, when its resistance to rot increased always on the $99.9 \%$ significance level (Reinprecht and Repák 2019), the anti-rot effect of the PEG-thermal modification modes was clearly lower (Table 1). This could also be caused by a washout of water soluble PEG macromolecules from modified wood during the mycological test - so an initial water washout of specimens by EN 84 (1997) would be appropriate.

As mentioned earlier, thermal modification of wood can induce a chemical transformation of its individual accompanying components, which also include minerals, vitamins, low molecular weight carbohydrates, and other substances responsible for the 
activity of wood decaying fungi. Upon thermal modification at high temperatures, hemicelluloses are degraded to less hygroscopic substances, such as polymers based on furfuryl alcohol and furfuryl aldehyde, which are toxic to fungal organisms (Kamdem et al. 2002; Boonstra et al. 2007).

As in the case of paraffin-thermally modified wood, the rot resistance was apparently increased (Reinprecht and Repák 2019) compared with other thermal modifications in line with rising temperature and extended modification time (Tjeerdsma et al. 2002; Welzbacher and Rapp 2002; Yilgör and Kartal 2010; Lacić et al. 2014). Even the impregnation of wood with paraffin and other hydrophobic substances deposited on the outer surface of the wood and on the surface $S_{3}$ of the cell wall layer, and forming a continuous and solid waxy layers, can slow degradation of wood by decaying fungi without its thermal modification. Hydrophobic paraffin after cooling and solidification in lumina of wood cells indirectly inhibits rotting processes in wood. When present in the wood, the wax more reliably creates a mechanical barrier with inhibiting effect against decaying fungi - i.e., paraffin slows down the diffusion of enzymes and degradation products between the decaying fungus and the wood, and it also slows down the process of absorption of water molecules to wood by blocking of its cell walls (Wang and Cooper 2005; Awoyemi et al. 2009; Lesar and Humar 2011; Dubey et al. 2012).

Comparing analogous methods of wood thermall modification in melts, i.e., the paraffin-thermal method (Reinprecht and Repák 2019) and the PEG-thermal method present in this work, it can be concluded that PEG 6000 has a lower inhibitory effect against rot by decaying fungi compared to paraffin. This can be attributed mainly to the hydrophilic nature of PEG. So, when a decay process in wood occurs, its moisture gradually increases, and such effect can results in a reduction in the concentration of PEG macromolecules in the wood as well as in their partial leaching from the wood. The degree of polymerization and the 3D spatial size of PEG macromolecules can also be reduced at high temperatures, for example, due to thermal-oxidative degradation processes at thermal modification, in connection with the formation of low molecular weight esters (Han et al. 1997).

\section{Soaking and Swelling of the PEG-Thermally Treated Beech Wood}

As already mentioned, several studies have indicated that there is a link between the weight loss of wood during thermal modification and its water absorbency and swelling (Almeida et al. 2009; Bal and Bektaş 2012; Bal 2013). More obvious connections occur mainly at higher modification temperatures when the degradation and crosslinking of wood components has a greater effect on increasing its hydrophobicity. Thermal modification of wood changes its molecular structure as polysaccharides (especially hemicelluloses) depolymerize, the proportion of crystalline cellulose increases, and lignin crosslinks, reducing the proportion and availability of free hydroxyl groups in wood (Boonstra et al. 2007a).

In the soaking test, the liquid water absorbency $\left(S_{\mathrm{i}}\right)$ of the beech wood thermally modified in PEG 6000 at $190{ }^{\circ} \mathrm{C}$ and $210{ }^{\circ} \mathrm{C}$ was clearly reduced, the most in the mode $210{ }^{\circ} \mathrm{C} / 4 \mathrm{~h}$ - after $24 \mathrm{~h}$ of soaking from $55.21 \%$ to $20.55 \%$, i.e., by $62.8 \%$ (Table 2, Fig. 4), and after $336 \mathrm{~h}$ of soaking from $93.55 \%$ to $37.45 \%$, i.e., by $60.0 \%$ (Table 2). However, the PEG-heated beech specimens, i.e., exposed only at a temperature of $100{ }^{\circ} \mathrm{C}$, showed paradoxically even lower $S_{\mathrm{i}}$ values (Table 2, Fig. 4). This result can be attributed to higher $W P G$ values of PEG 6000 at $100{ }^{\circ} \mathrm{C}$ compared to those $W P G^{*}$ ones at 190 and $210^{\circ} \mathrm{C}$ (Fig. $3)$. The melt of PEG 6000 gradually filled up the pores - lumina of the PEG-thermally treated specimens. However, with prolonged treatment time ( $4^{\text {th }}$ phase in Fig. 2$)$ the amount 
of the PEG melt in specimens was almost the same for the given specimen type (a, b, c, or $\mathrm{d}-$ Fig. 1$)$ at the given used temperature $\left(100,190\right.$, or $210^{\circ} \mathrm{C}-$ Fig. 3$)$, probably because the specimens in previous phases $\left(1^{\text {st }}-3^{\text {rd }}\right.$ in Fig. 2) were already be sufficiently filled with the PEG, and the time effect in the $4^{\text {th }}$ phase (lasting from $1 \mathrm{~h}$ to $4 \mathrm{~h}$ ) of wood thermal treatment was not more or less negligible for its $S_{\mathrm{i}}$ values (Table 2).

Table 2. Water Absorbency $(S)$ of the PEG-Thermally Treated Beech Wood

\begin{tabular}{|c|c|c|}
\hline $\begin{array}{c}\text { Modes of Beech Wood } \\
\text { Treatment in PEG 6000 }\end{array}$ & $\begin{array}{c}\text { Soaking } \\
\mathbf{S}_{\mathbf{i}}(\mathbf{\%}) \mathbf{- 2 4} \mathbf{~ h}\end{array}$ & $\begin{array}{c}\text { Soaking } \\
\boldsymbol{S}_{\mathbf{i}}(\mathbf{\%}) \mathbf{- 3 3 6 ~} \mathbf{~}\end{array}$ \\
\hline Reference & $55.21(0.59)$ & $93.55(1.29)$ \\
\hline $100^{\circ} \mathrm{C} / 1 \mathrm{~h}$ & $15.69(1.79) \mathrm{a}$ & $37.51(3.48) \mathrm{a}$ \\
\hline $100^{\circ} \mathrm{C} / 2 \mathrm{~h}$ & $14.21(0.85) \mathrm{a}$ & $36.84(2.88) \mathrm{a}$ \\
\hline $100^{\circ} \mathrm{C} / 3 \mathrm{~h}$ & $16.79(1.08) \mathrm{a}$ & $40.03(2.90) \mathrm{a}$ \\
\hline $100^{\circ} \mathrm{C} / 4 \mathrm{~h}$ & $16.83(1.84) \mathrm{a}$ & $42.64(3.24) \mathrm{a}$ \\
\hline $190^{\circ} \mathrm{C} / 1 \mathrm{~h}$ & $28.20(5.13) \mathrm{a}$ & $48.94(8.83) \mathrm{a}$ \\
\hline $190^{\circ} \mathrm{C} / 2 \mathrm{~h}$ & $28.67(3.60) \mathrm{a}$ & $50.29(6.03) \mathrm{a}$ \\
\hline $190^{\circ} \mathrm{C} / 3 \mathrm{~h}$ & $26.77(2.38) \mathrm{a}$ & $50.35(3.85) \mathrm{a}$ \\
\hline $190^{\circ} \mathrm{C} / 4 \mathrm{~h}$ & $25.60(1.35) \mathrm{a}$ & $47.78(2.91) \mathrm{a}$ \\
\hline $210^{\circ} \mathrm{C} / 1 \mathrm{~h}$ & $26.78(2.18) \mathrm{a}$ & $46.06(3.07) \mathrm{a}$ \\
\hline $210^{\circ} \mathrm{C} / 2 \mathrm{~h}$ & $24.06(1.39) \mathrm{a}$ & $45.83(2.40) \mathrm{a}$ \\
\hline $210^{\circ} \mathrm{C} / 3 \mathrm{~h}$ & $23.21(3.40) \mathrm{a}$ & $43.10(6.10) \mathrm{a}$ \\
\hline $210^{\circ} \mathrm{C} / 4 \mathrm{~h}$ & $20.55(3.27) \mathrm{a}$ & $37.45(5.06) \mathrm{a}$ \\
\hline
\end{tabular}

Note: Average values were determined from 6 specimens. Standard deviations (SD) are in parentheses.

The Duncan test was performed in relation to reference samples with significance levels of: $a=99.9 \%$, $b=99 \%, c=95 \%$, and $d<95 \%$
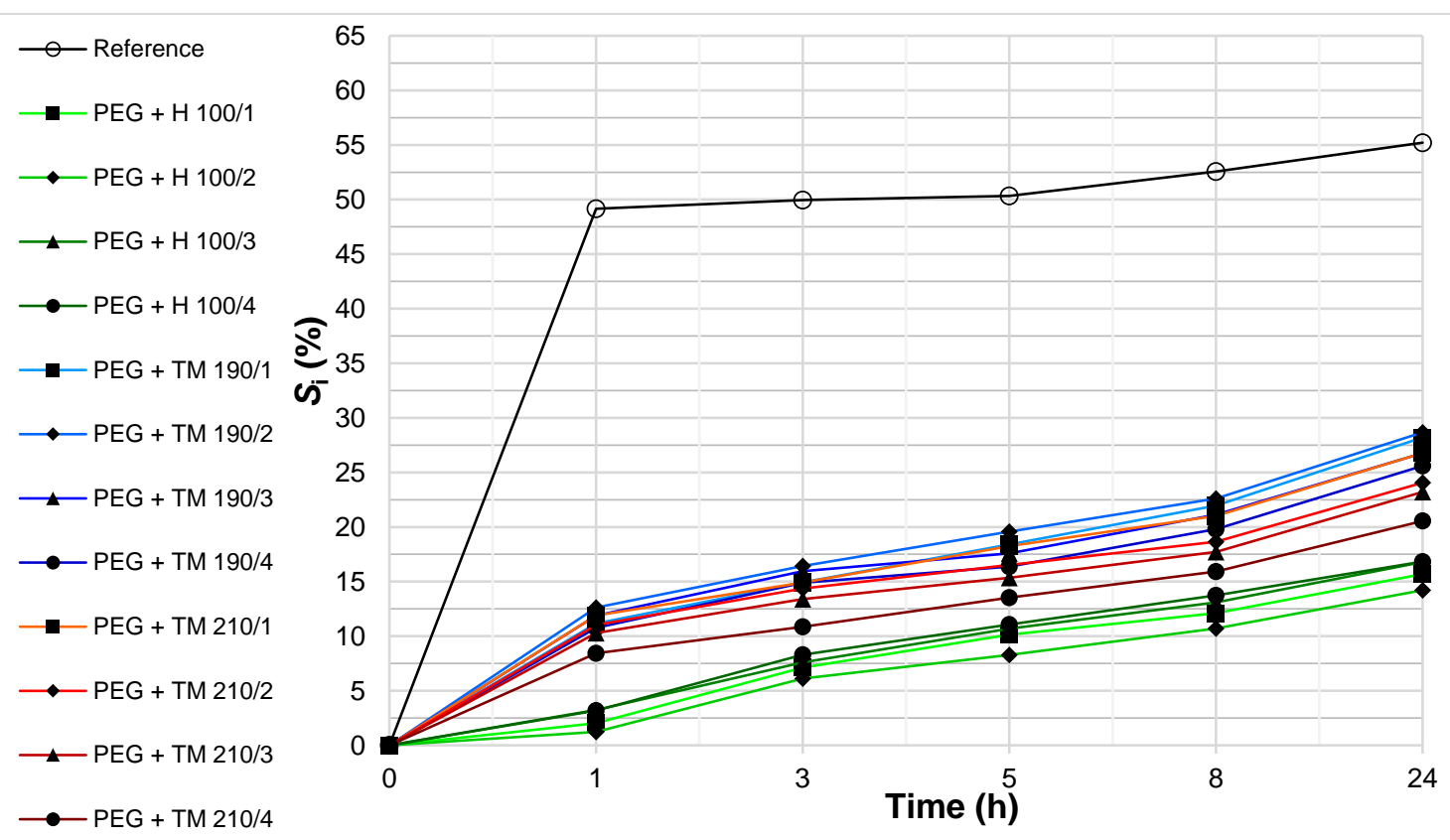

Fig. 4. Soaking $\left(S_{\mathrm{i}}\right)$ kinetics of the reference, PEG-heated $\left(100^{\circ} \mathrm{C}\right)$, and PEG-thermally modified $\left(190^{\circ} \mathrm{C}\right.$ and $\left.210^{\circ} \mathrm{C}\right)$ beech wood

The higher WPG values of polyethylene glycol molecules achieved at $100{ }^{\circ} \mathrm{C}$ can be explained by these hypotheses: (1) a relatively higher viscosity of PEG 6000 at $100{ }^{\circ} \mathrm{C}$ than at 190 or $210^{\circ} \mathrm{C}$, which means that its macromolecules after termination the heating 
process flowed less from the wood and a relatively larger amount of the solidified PEG 6000 remained near of the surface or also in the volume of beech specimens, where it acted as a mechanical barrier and reduced the kinetics of water absorption into the wood; (2) a thermo-oxidation of PEG 6000 at 190 and $210{ }^{\circ} \mathrm{C}$, reducing the degree of polymerization and 3D size of newly formed macromolecules, in connection with the formation of low molecular weight esters (Han et al. 1996), which could more easily flow out of the modified wood before their solidification phase; (3) an increased mass loss of beech wood during its thermal modification in PEG 6000 ( $\Delta m$ Thermal), mainly in connection with degradation of hemicelluloses at 190 and $210{ }^{\circ} \mathrm{C}$.

The volume swelling $\left(\beta V_{1}\right)$ of beech wood thermally modified in PEG 6000 at 190 or $210{ }^{\circ} \mathrm{C}$ decreased in proportion to increasing modification temperature and time (Table 3, Fig. 5).

Table 3. Volume Swelling $\left(\beta \mathrm{v}_{i}\right)$ of the PEG-Thermally Treated Beech Wood

\begin{tabular}{|c|c|c|}
\hline $\begin{array}{c}\text { Modes of Beech Wood } \\
\text { Treatment in PEG 6000 }\end{array}$ & $\begin{array}{c}\text { Volume Swelling } \\
\boldsymbol{\beta}_{\mathrm{vi}}(\%)-\mathbf{2 4} \mathbf{~ h}\end{array}$ & $\begin{array}{c}\text { Volume Swelling } \\
\boldsymbol{\beta}_{\mathbf{v i}}(\%)-\mathbf{3 3 6 ~} \mathbf{~}\end{array}$ \\
\hline Reference & $21.35(2.64)$ & $24.08(2.39)$ \\
\hline $100^{\circ} \mathrm{C} / 1 \mathrm{~h}$ & $20.12(1.86) \mathrm{d}$ & $23.11(1.66) \mathrm{d}$ \\
\hline $100^{\circ} \mathrm{C} / 2 \mathrm{~h}$ & $20.57(2.56) \mathrm{d}$ & $24.53(2.33) \mathrm{d}$ \\
\hline $100^{\circ} \mathrm{C} / 3 \mathrm{~h}$ & $20.15(1.61) \mathrm{d}$ & $22.41(1.41) \mathrm{d}$ \\
\hline $100^{\circ} \mathrm{C} / 4 \mathrm{~h}$ & $20.49(1.64) \mathrm{d}$ & $22.78(1.61) \mathrm{d}$ \\
\hline $190^{\circ} \mathrm{C} / 1 \mathrm{~h}$ & $20.05(1.84) \mathrm{d}$ & $22.98(1.49) \mathrm{d}$ \\
\hline $190^{\circ} \mathrm{C} / 2 \mathrm{~h}$ & $20.01(1.71) \mathrm{d}$ & $22.32(1.32) \mathrm{d}$ \\
\hline $190^{\circ} \mathrm{C} / 3 \mathrm{~h}$ & $17.07(1.74) \mathrm{a}$ & $20.09(1.22) \mathrm{a}$ \\
\hline $190^{\circ} \mathrm{C} / 4 \mathrm{~h}$ & $16.55(1.44) \mathrm{a}$ & $18.94(1.10) \mathrm{a}$ \\
\hline $210^{\circ} \mathrm{C} / 1 \mathrm{~h}$ & $18.70(1.77) \mathrm{a}$ & $21.21(1.52) \mathrm{c}$ \\
\hline $210^{\circ} \mathrm{C} / 2 \mathrm{~h}$ & $15.82(1.67) \mathrm{a}$ & $18.76(1.36) \mathrm{a}$ \\
\hline $210^{\circ} \mathrm{C} / 3 \mathrm{~h}$ & $14.47(2.79) \mathrm{a}$ & $17.59(3.05) \mathrm{a}$ \\
\hline $210^{\circ} \mathrm{C} / 4 \mathrm{~h}$ & $13.30(1.44) \mathrm{a}$ & $15.76(1.05) \mathrm{a}$ \\
\hline
\end{tabular}

Note: Average values were determined from 6 specimens. Standard deviations (SD) are in parentheses. The Duncan test was performed in relation to reference samples with significance levels of: $a=99.9 \%, b=99 \%, c=95 \%$, and $d<95 \%$ 


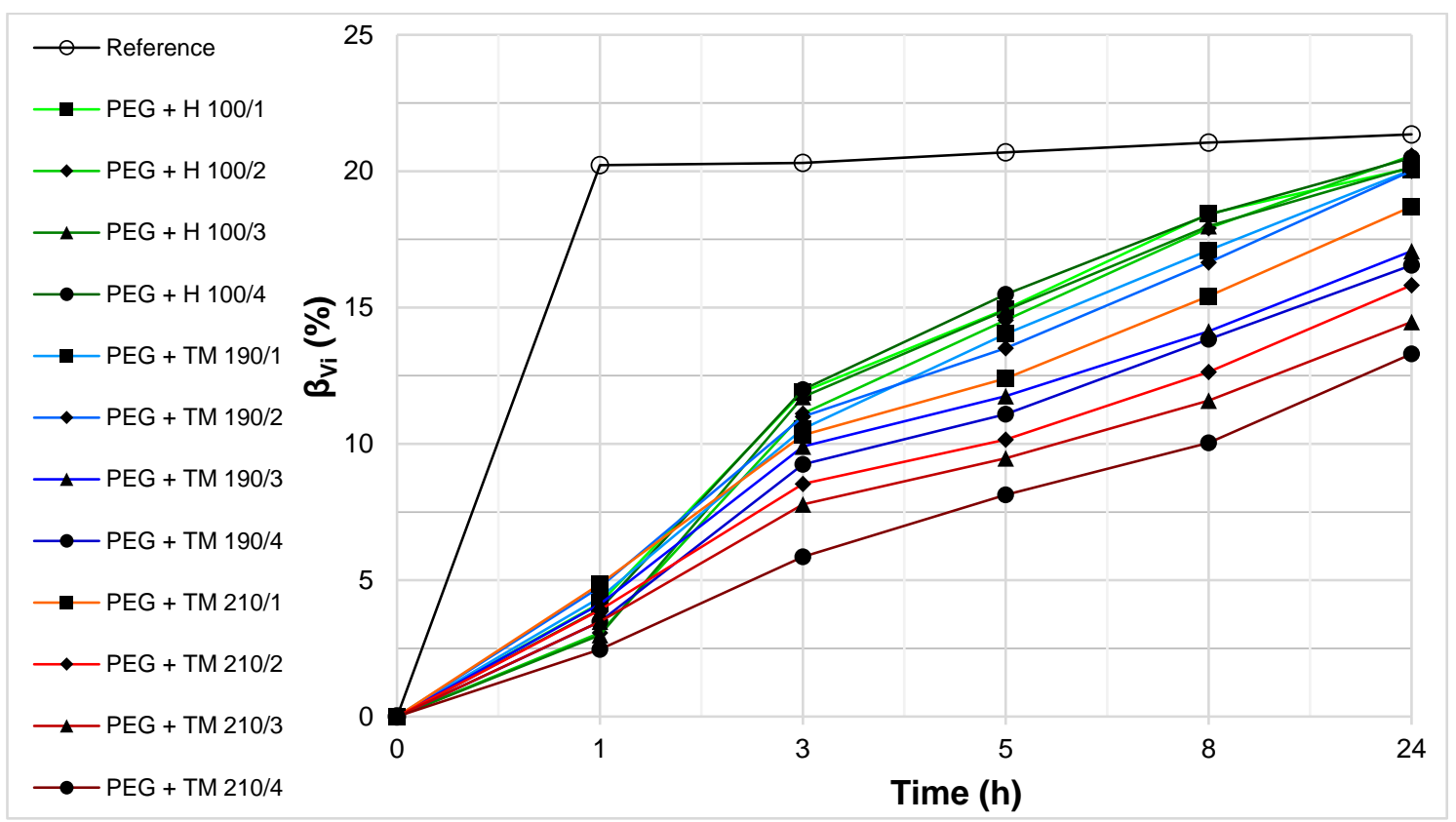

Fig. 5. Volume swelling kinetics of the reference, PEG-heated $\left(100^{\circ} \mathrm{C}\right)$, and PEG thermally modified $\left(190^{\circ} \mathrm{C}\right.$ and $\left.210^{\circ} \mathrm{C}\right)$ beech wood

For example, the swelling after $336 \mathrm{~h}$ was reduced maximally by $34.6 \%$ in specimens modified with mode $210{ }^{\circ} \mathrm{C} / 4 \mathrm{~h}$ (Table 3 ). However, the swelling of the PEGheated beech wood exposed to $100{ }^{\circ} \mathrm{C}$ did not decrease significantly after 24 and $336 \mathrm{~h}$ (Table 3) - at which point only the rate of swelling in the first hours decreased (Fig. 5). PEG 6000 consists of relatively long linear macromolecules with a degree of polymerization from 130 to 140. The transport of polar PEG 6000 from cell lumens to cell walls of wood is usually minimal, as it is limited by the dimensions of its macromolecules and the dimensions of the wood cell micro-pores (Tarkow et al. 1966; Jeremic and Cooper 2007; Fejfer et al. 2020). This means that PEG 6000 could not theoretically have a significant effect on the final stabilization of wood dimensions at the swelling test, so its presence in the wood only slows down the rate of wood swelling.

The decreased volume swelling of the thermally modified beech wood specimens (Table 3) coincided well with their weight losses $\Delta m_{\text {Thermal }}$ (Figs. 3e and 3d) determined at the modification temperatures of 190 and $210{ }^{\circ} \mathrm{C}$, in accordance with degradation of hemicelluloses and reduction the number of hydroxyl groups in all structural elements of wood (Hill 2006; Esteves and Pereira 2009; Sandberg et al. 2021).

\section{Color of the PEG-Thermally Treated Beech Wood}

A considerable effect on the color of beech wood in the presence of PEG 6000 was observed for heating at $100{ }^{\circ} \mathrm{C}$, but more so the thermal modification modes at 190 and $210{ }^{\circ} \mathrm{C}$. The color of beech wood changed more intensively at higher temperatures and longer times of thermal treatment (Table 4, Fig. 6). Using the conditions in Cividini et al. (2007), the total color difference of the PEG-thermally treated beech wood specimens was always high, with $\Delta E^{*} \geq 12$, i.e., it was visible as well as by a human eye (Table 4 ). 
Table 4. Color Changes of the PEG-Heated and PEG-Thermally Modified Beech Wood Specimens

\begin{tabular}{|c|c|c|c|c|}
\hline \multirow{2}{*}{$\begin{array}{c}\text { Modes of Beech Wood } \\
\text { Treatment in PEG 6000 }\end{array}$} & \multicolumn{4}{|c|}{ Changed Color Parameter } \\
\cline { 2 - 5 } & $\boldsymbol{\Delta E}_{\boldsymbol{a b}}{ }^{*}$ & $\boldsymbol{\Delta a}^{*}$ & $\boldsymbol{\Delta b}^{*}$ & $\boldsymbol{\Delta L}^{*}$ \\
\hline $100^{\circ} \mathrm{C} / 1 \mathrm{~h}$ & $13.13(0.73)$ & $5.7(0.6)$ & $4.8(0.2)$ & $-10.8(0.7)$ \\
\hline $100^{\circ} \mathrm{C} / 2 \mathrm{~h}$ & $14.52(0.52)$ & $5.0(3.4)$ & $4.9(0.3)$ & $-12.3(0.2)$ \\
\hline $100^{\circ} \mathrm{C} / 3 \mathrm{~h}$ & $14.40(1.13)$ & $6.2(0.7)$ & $5.8(0.5)$ & $-11.6(0.9)$ \\
\hline $100^{\circ} \mathrm{C} / 4 \mathrm{~h}$ & $14.17(0.59)$ & $5.7(0.5)$ & $5.3(0.5)$ & $-11.8(0.4)$ \\
\hline $190^{\circ} \mathrm{C} / 1 \mathrm{~h}$ & $24.12(1.22)$ & $5.5(0.4)$ & $5.0(0.8)$ & $-22.9(1.4)$ \\
\hline $190^{\circ} \mathrm{C} / 2 \mathrm{~h}$ & $34.47(2.04)$ & $5.8(1.1)$ & $3.5(0.8)$ & $-33.8(1.9)$ \\
\hline $190^{\circ} \mathrm{C} / 3 \mathrm{~h}$ & $43.50(1.15)$ & $4.0(0.9)$ & $-2.3(0.7)$ & $-43.2(1.2)$ \\
\hline $190^{\circ} \mathrm{C} / 4 \mathrm{~h}$ & $38.84(1.39)$ & $3.0(1.2)$ & $-4.3(0.7)$ & $-38.5(1.4)$ \\
\hline $210^{\circ} \mathrm{C} / 1 \mathrm{~h}$ & $36.01(1.71)$ & $5.9(0.5)$ & $2.6(0.4)$ & $-35.4(1.7)$ \\
\hline $210^{\circ} \mathrm{C} / 2 \mathrm{~h}$ & $43.90(2.27)$ & $4.1(0.3)$ & $-4.3(0.6)$ & $-43.5(2.3)$ \\
\hline $210^{\circ} \mathrm{C} / 3 \mathrm{~h}$ & $52.57(0.46)$ & $-1.6(0.6)$ & $-11.9(0.6)$ & $-51.2(0.4)$ \\
\hline $210^{\circ} \mathrm{C} / 4 \mathrm{~h}$ & $51.00(0.33)$ & $-3.8(0.7)$ & $-12.9(0.9)$ & $-49.2(0.5)$ \\
\hline
\end{tabular}

Notes: Arithmetic means were determined from 8 values (2 specimens with 4 measured places); standard deviations are in parentheses; color coordinates of the reference (thermally untreated without presence of PEG) beech wood specimens: $a^{*}=7.7, b^{*}=15.8, L^{*}=78.8$

The color of wood affects the appearance of the final wooden product. It depends on its chemical components, i.e., cellulose, hemicelluloses, lignin, and mainly extractives. In addition to the temperature and time of thermal treatment, the change in the color of the wood is also influenced by the environment in which the thermal modification of the wood takes place. Thermally modified wood acquires a dark-brown caramel shade in its entire cross-section, while more intense color changes of wood occur in response to higher modification temperatures and prolonged thermal modification time (Sailer et al. 2000; Bekhta and Niemz 2003; Srinivas and Pandley 2012; Cirule et al. 2021). 


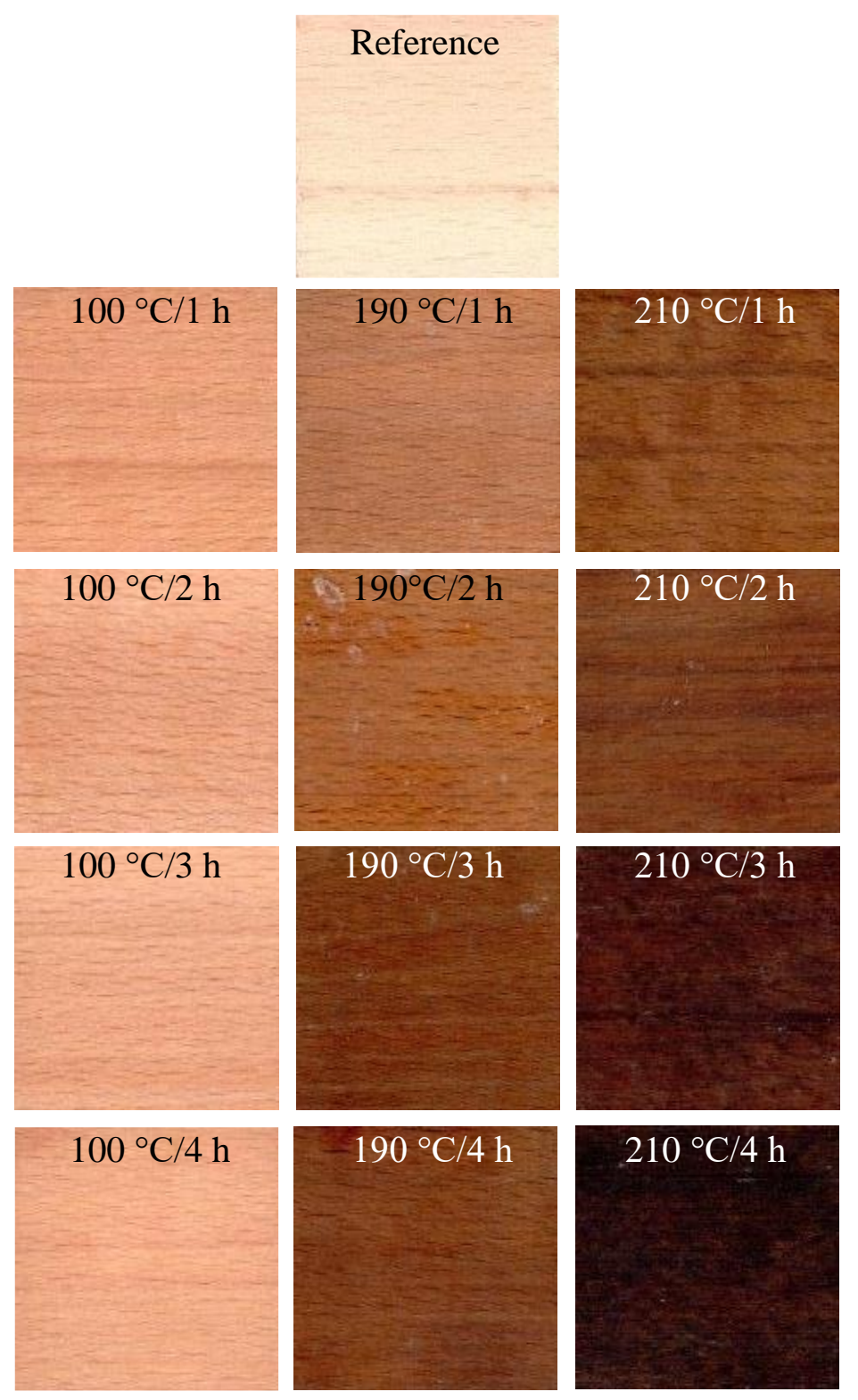

Fig. 6. Darkening of the PEG-thermally treated beech wood specimens - PEG-heated at $100^{\circ} \mathrm{C}$ and PEG-thermally modified at 190 or $210^{\circ} \mathrm{C}$

A darkening of wood exposed to higher temperatures is generally attributed in particular to the decomposition of hemicelluloses and the chemical changes in extractives (Sundqvist and Morén 2002; Sehlstedt-Persson 2003; Esteves et al. 2008). According to Pelit (2016), a darkening of densified wood increased at the thermal-post treatments with application of higher temperatures from 190 to $210{ }^{\circ} \mathrm{C}$ and more for specimens having a higher compression ratio. Woods, bamboos or other plants obtain dark-brown colors as well as at their laser irradiation, when $\Delta L^{*}$ and $\Delta E^{*}$ increase with the enhancement of laser power (Vidholdová et al. 2017; Li et al. 2020). However, usually only thermal modification techniques can be an efficient and ecological way to change color of wood throughout its cross-section and without the use of chemicals (Johansson and Morén 2006; González-Pena and Hale 2009; Chen et al. 2012). 
All beech wood specimens heated in the melt of PEG 6000 at $100{ }^{\circ} \mathrm{C}$ from $1 \mathrm{~h}$ to 4 h obtained darker ( $\Delta L^{*}$ approximately -11$)$, redder ( $\Delta a^{*}$ approximately 5.5), and yellower $\left(\Delta b^{*}\right.$ approximately 5) shades, with the total color difference $\Delta E_{a b} *$ approximately 14 (Table 4, Fig. 6).

At higher modification temperatures of 190 and $210{ }^{\circ} \mathrm{C}$ the beech wood specimens acquired an even darker shade ( $\Delta L^{*}$ from -22.9 to -51.2$)$; however, they gradually also acquired greener and bluer shades ( $\Delta a^{*}$ from 5.9 to $-3.8 ; \Delta b^{*}$ from 5.0 to -12.9 ) with the total color difference $\Delta E_{\mathrm{ab}} *$ from 24 to 52 (Tab. 4, Fig. 6). These results are in accordance with works of several researchers who thermally modified the wood in environment of hot oils (Tjeerdsma et al. 2005; Dubey et al. 2011), or when pre-impregnation of beech wood with hemp oil caused greater color changes at the following thermal treatment (Baar et al. 2020).

In this experiment, the color changes of PEG-thermally modified beech wood were greater than for beech wood thermally modified in air environment at the same temperatures and times (Repák and Reinprecht 2021) or at similar temperature and time conditions (Mitani and Barboutis 2014; Toker et al. 2016; Kúdela et al. 2020).

Sunqvist (2002) stated that oxidative and hydrolytic reactions are the main reasons for production of chromophores during thermal modification of wood, at which hydrolytic reactions are generally the dominant processes when in wood a water is present yet. However, in the anaerobic medium, such as in a melt of wax, formation of a wax layer on the thermally modified wood surface and caramelisation of soluble sugars made of wood hemicelluloses is a more probable explanation to the more intensive darkening effect.

\section{Impact Bending Strength and Brinell Hardness of the PEG-Thermally Treated Beech Wood}

The impact bending strength $(I)$ of beech wood decreased approximately about $34 \%$ after thermal treatments in PEG 6000 at the modes $210^{\circ} \mathrm{C} / 3 \mathrm{~h}$ and $210^{\circ} \mathrm{C} / 4 \mathrm{~h}$, i.e., at a 99.9\% significance level (Table 5). PEG 6000 alone had no significant effect on reducing the impact bending strength of beech wood. For heating in PEG 6000 melt at $100{ }^{\circ} \mathrm{C}$ for 2 , 3 , and $4 \mathrm{~h}$, and for thermal modification at $190{ }^{\circ} \mathrm{C} / 1 \mathrm{~h}$, the impact strength of beech wood even increased slightly. It is known that the reduction in impact strength of thermally modified wood occurs mainly due to the thermal degradation of hemicelluloses in the cell walls of the wood and also due to the influence of aggressive organic acids formed during decomposition of hemicelluloses (Zaman et al. 2000). In theory, dimensionally large macromolecules PEG 6000 do not penetrate the cell walls of wood, and thus they should not decrease its bending strength.

The Brinell hardness $\left(H_{\mathrm{B}}\right)$ of thermally treated beech wood decreased with increasing temperature and time of treatment, with a decrease in the range of $12.7 \%$ to $43.3 \%$, the most at $210^{\circ} \mathrm{C}$ (Table 5). Beech wood heated in PEG 6000 at $100{ }^{\circ} \mathrm{C}$ had lower values of $H_{\mathrm{B}}$, approximately by $15.4 \%$, compared to $H_{\mathrm{B}}$ values of reference beech wood. This means that the solidified PEG 6000 with a waxy consistency itself also could partly contribute to the decrease in wood hardness. This assumption is based on the possibility that the waxy PEG present in lumina of wood cells can improve sliding and reduce the resistance of specimen to the penetrating - pressed steel ball used at the Brinnell hardness determination. This is also in an accordance with results obtained by Repák and Reinprecht (2020), who thermally modified beech wood pretreated with $20 \mathrm{wt} \%$ water solution of PEG 6000 . 
Table 5. Impact Bending Strength $(I)$ and Brinell Hardness $\left(H_{\mathrm{B}}\right)$ of the PEGThermally Treated Beech Wood

\begin{tabular}{|c|c|c|}
\hline $\begin{array}{c}\text { Modes of Beech Wood } \\
\text { Treatment in PEG } \mathbf{6 0 0 0}\end{array}$ & $\begin{array}{c}\text { Impact Bending Strength } \\
\boldsymbol{I}\left(\mathbf{J . c m}^{-2}\right)\end{array}$ & $\begin{array}{c}\text { Brinell Hardness } \\
\boldsymbol{H}_{\boldsymbol{B}}(\mathbf{M P a})\end{array}$ \\
\hline Reference & $5.53(0.65)$ & $38.16(5.96)$ \\
\hline $100^{\circ} \mathrm{C} / 1 \mathrm{~h}$ & $5.35(0.39) \mathrm{d}$ & $33.30(7.78) \mathrm{d}$ \\
\hline $100^{\circ} \mathrm{C} / 2 \mathrm{~h}$ & $6.45(0.67) \mathrm{c}$ & $32.75(5.52) \mathrm{d}$ \\
\hline $100^{\circ} \mathrm{C} / 3 \mathrm{~h}$ & $6.00(0.66) \mathrm{d}$ & $31.89(9.40) \mathrm{d}$ \\
\hline $100^{\circ} \mathrm{C} / 4 \mathrm{~h}$ & $5.88(0.73) \mathrm{d}$ & $31.17(4.22) \mathrm{d}$ \\
\hline $190^{\circ} \mathrm{C} / 1 \mathrm{~h}$ & $6.06(0.34) \mathrm{d}$ & $29.70(5.27) \mathrm{d}$ \\
\hline $190^{\circ} \mathrm{C} / 2 \mathrm{~h}$ & $4.69(0.35) \mathrm{d}$ & $28.65(4.55) \mathrm{c}$ \\
\hline $190^{\circ} \mathrm{C} / 3 \mathrm{~h}$ & $4.70(0.22) \mathrm{c}$ & $28.28(6.29) \mathrm{c}$ \\
\hline $190^{\circ} \mathrm{C} / 4 \mathrm{~h}$ & $4.79(0.95) \mathrm{d}$ & $26.34(4.23) \mathrm{b}$ \\
\hline $210^{\circ} \mathrm{C} / 1 \mathrm{~h}$ & $5.02(0.60) \mathrm{d}$ & $27.45(6.95) \mathrm{c}$ \\
\hline $210^{\circ} \mathrm{C} / 2 \mathrm{~h}$ & $4.79(0.30) \mathrm{d}$ & $25.64(4.69) \mathrm{b}$ \\
\hline $210^{\circ} \mathrm{C} / 3 \mathrm{~h}$ & $3.68(0.53) \mathrm{a}$ & $22.03(4.41) \mathrm{a}$ \\
\hline $210^{\circ} \mathrm{C} / 4 \mathrm{~h}$ & $3.65(0.70) \mathrm{a}$ & $21.63(5.39) \mathrm{a}$ \\
\hline
\end{tabular}

Note: Average values were determined from 6 specimens. Standard deviations (SD) are in parentheses.

The Duncan test was performed in relation to reference samples with significance levels of: $a=99.9 \%, b=$ $99 \%, c=95 \%$, and $d<95 \%$.

Generally, the achieved results for the Brinell hardness are consistent with knowledge of other researchers who analyzed hardness of beech wood thermally modified by various techniques (Reinprecht and Vidholdová 2008; Borůvka et al. 2018; Lunguleasa et al. 2018).

\section{CONCLUSIONS}

1. Thermal modification of beech wood in the melt of PEG 6000 at 190 and $210{ }^{\circ} \mathrm{C}$ had a positive effect on increasing its resistance to rot. It improved maximally due to the modification mode $210{ }^{\circ} \mathrm{C} / 4 \mathrm{~h}$ - to the brown-rot fungus Poria placenta by $60.3 \%$ and to the white-rot fungus Trametes versicolor by $62.8 \%$.

2. The liquid water absorbency of the PEG-thermally treated beech wood was significantly reduced, usually by at least half. However, its volumetric swelling apparently decreased only at the most severe modification modes, i.e., at using the temperatures of 190 and $210^{\circ} \mathrm{C}$ for at least 3 and $4 \mathrm{~h}$.

3. The total color differences of the all PEG-heated and PEG-thermally modified beech wood specimens were always significant, i.e., the $\Delta E_{\mathrm{ab}} *$ were greater than 12 . Specimens that were treated at the temperatures of 190 and $210^{\circ} \mathrm{C}$ apparently darkened $\left(\Delta L^{*}\right.$ from -23 to -51$)$ and also had evident changes of the other two color coordinates $\left(\Delta a^{*}, \Delta b^{*}\right)$.

4. The impact strength of the PEG-thermally modified beech wood was reduced, however, by more than by $16 \%$ only when it was exposed to $210^{\circ} \mathrm{C}$ for 3 and $4 \mathrm{~h}$.

5. The decrease in Brinell hardness of the PEG-thermally modified beech wood was more even with increasing modification temperature and time, up to a maximum of $43.3 \%$. The assumption was made that hardness decreased not only due to the thermal 
degradation of wood components, but also due to the softening effect of PEG 6000 present in lumens and on surfaces of the $S_{3}$ layer of the wood cell walls.

\section{ACKNOWLEDGMENTS}

This work was supported by the Slovak Research and Development Agency under the contract No. APVV-17-0583.

\section{REFERENCES CITED}

Almeida, G., Brito, J. O., and Perre, P. (2009). "Changes in wood-water relationship due to heat treatment assessed on micro-samples of three Eucalyptus species,"

Holzforschung 63(1), 80-88. DOI: 10.1515/HF.2009.026

Awoyemi, L., Cooper, P. A., and Ung, T. Y. (2009). "In-treatment cooling during thermal modification of wood in soy oil medium: Soy oil uptake, wettability, water uptake and swelling properties," European Journal of Wood and Wood Products 67(4), 465470. DOI: $10.1007 / \mathrm{s} 00107-009-0346-9$

Almkvist, G., Norbakhsh, S., Bjurhager, I., and Varmuza, K. (2016). "Prediction of tensile strength in iron-contaminated archaeological wood by FT-IR spectroscopy - A study of degradation in recent oak and Vasa oak," Holzforschung 70(9), 855-865. DOI: $10.1515 / \mathrm{hf}-2015-0223$

Baar, J., Brabec, M., Slávik, R., and Čermák, P. (2020). "Effect of hemp oil impregnation and thermal modification on European beech wood properties," European Journal of Wood and Wood Products 79(1), 161-175. DOI: 10.1007/s00107-020-01615-9

Bal, B. C., and Bektaş, I. (2012). "The effects of heat treatment on the physical properties of juvenile wood and mature wood of E. grandis," BioResources 7(4), 5117-5127. DOI: 10.15376/biores.7.4.5117-5127

Bekhta, P., and Niemz, P. (2003). "Effect of high temperature on the change in color, dimensional stability and mechanical properties of spruce wood," Holzforschung 57(5), 539-546. DOI: 10.1515/HF.2003.080

Boonstra, M. J., Van Acker, J., Kegel, E., and Stevens, M. (2007). “Optimisation of a two- stage heat treatment process: Durability aspects," Wood Science and Technology 41(1), 31-57. DOI: 10.1007/s00226-006-0087-4

Borůvka, V., Zeidler, A., Holeček, T., and Dudík, R. (2018). "Elastic and strength properties of heat-treated beech and birch wood," Forests 9(4/197), 1-17. DOI: 10.3390/f9040197

Cai, C., Antikainen, J., Luostarinen, K., Mononen, K., and Herajarvi, H. (2018). "Wetting-induced changes on the surface of thermally modified Scots pine and Norway spruce wood," Wood Science and Technology 52(5), 1181-1193. DOI: 10.1007/s00226-018-1030-1

Chen, Y., Fan, Y., Gao, J., and Stark, N. M. (2012). "The effect of heat treatment on the chemical and color change of black locust (Robinia pseudoacacia) wood during heat treatment," BioResources 7(1), 1157-1170. DOI: 10.15376/biores.7.1.1157-1170

CIE (2007). Colorimetry - Part 4: CIE 1976 L*a*b* COLOUR SPACE. CIE DS 0144.3/E:2007, CIE Central Bureau, Vienna, Austria. 
Cirule, D., Sansonetti, E., Andersone, I., Kuka, E., and Andersons, B. (2021). "Enhancing thermally modified wood stability against discoloration," Coatings 11(1), 1-13. DOI: 10.3390/coatings 11010081

Cividini, R., Travan, L., and Allegretti, O. (2007). "White beech: A tricky problem in drying process," NARDI Srl, Italy, http://www.ivalsa.cnr.it/ISCHP07/CividiniTravanAllegretti, pdf

Dubey, M. K., Pang S., and Walker, J. (2012). "Changes in chemistry, color, dimensional stability and fungal resistance of Pinus radiata D. Don wood with oil heat-treatment," Holzforschung 66(1), 49-57. DOI: 10.1515/HF.2011.117

EN 84 (1997). "Wood preservatives. Accelerated ageing of treated wood prior to biological testing. Leaching procedure," European Committee for Standardization, Brussels, Belgium.

EN 113 (1996). "Wood preservatives - Test method for determining the protective effectiveness against wood destroying basidiomycetes. Determination of the toxic values," European Committee for Standardization, Brussels, Belgium.

EN 350 (2016). "Durability of wood and wood-based products - Testing and classification of the durability to biological agents of wood and wood-based materials," European Committee for Standardization, Brussels, Belgium.

EN 1534 (2020). "Wood flooring and parquet - Determination of resistance to indentation - Test method," European Committee for Standardization, Brussels, Belgium.

EN ISO 3348 (1975). "Wood - Determination of impact bending strength," European Committee for Standardization, Brussels, Belgium.

Esteves, B. M., Domingos, I. J., and Pereira, H. M. (2008). "Pine wood modification by heat treatment in air," BioResources 3(1), 142-154. DOI: 10.15376/biores.3.1.142154

Esteves, B., and Pereira, H. M. (2009). "Wood modification by heat treatment: A review," BioResources 4(1), 370-404. DOI: 10.15376/biores.4.1.Esteves

Esteves, B., Nunes, L., Domingos, I., and Pereira, H. (2014). "Improvement of termite resistance, dimensional stability and mechanical properties of pine wood by paraffin impregnation," European Journal of Wood and Wood Products 72(5), 609-615. DOI: 10.1007/s00107-014-0823-7

Fejfer, M., Majka, J., and Zborowska, M. (2020). "Dimensional stability of waterlogged scots pine wood treated with PEG and dried using an alternative approach," Forests 11(12), 1-13. DOI: 10.3390/f11121254

González-Peña, M. M., and Hale, M. D. C. (2009). "Colour in thermally modified wood of beech, Norway spruce and Scots pine. Part 1: Colour evolution and colour changes," Holzforschung 63(4), 385-393. DOI: 10.1515/HF.2009.078

Han, S., Kim, C., and Kwon, D. (1997). "Thermal/oxidative degradation and stabilization of polyethylene glycol," Polymer 38(2), 317-323. DOI: 10.1016/S00323861(97)88175-X

Hasan, M., Despot, R., Šafran, B., Lacić, R., and Peršinović, M. (2008). “Oil heat treatment of alder wood for increasing biological durability of wood," in: Wood is Good - Properties, Technology, Valorisation, Application, University of Zagreb, Faculty of Forestry, Zagreb, Croatia, pp.121-125. ISBN 953292004-8

Hill, C. A. S. (2006). Wood Modification - Chemical, Thermal and Other Processes, John Wiley \& Sons, Ltd., Chichester, UK. 
Hocker, E., Almkvist, G., and Sahlstedt, M. (2012). "The Vasa experience with polyethylene glycol: A conservator's perspective," Journal of Cultural Heritage 13(3), 175-182. DOI: 10.1016/j.culher.2012.01.017

Jeremic, D., and Cooper, P. (2009). "PEG quantification and examination of molecular weight distribution in wood cell walls," Wood Science and Technology 43(3), 317329. DOI: $10.1007 / \mathrm{s} 00226-008-0233-2$

Johansson, D., and Morén, T. (2006). "The potential of colour measurement for strength prediction of thermally treated wood," Holz als Roh- und Werkstoff 64(2), 104-110. DOI: $10.1007 / \mathrm{s} 00107-005-0082-8$

Kamdem, D. P., Pizzi, A., and Jermannaud, A. (2002). "Durability of heat treated wood," Holz als Roh- und Werkstoff 60(1), 1-6. DOI: 10.1007/s00107-001-0261-1

Kocaefe, D., Huangl, X., and Kocaefe, Y. (2015). "Dimensional stabilization of wood," Current Forestry Reports 1(3), 151-161. DOI: 10.1007/s40725-015-0017-5

Kúdela, J., Lagaňa, R., Andor, T., and Csiha, C. (2020). "Variations in beech wood surface performance associated with prolonged heat treatment at $200{ }^{\circ} \mathrm{C}$," Acta Facultatis Xylologiae Zvolen 62(1), 5-17. DOI: 10.17423/afx.2020.62.1.01

Lacić, H., Hasan, M., Trajković, J., Šefc, B., Šafran, B., and Despot, R. (2014). "Biological durability of oil-heat treated alder wood," European Journal of Wood and Wood Products 69(2), 231-238. DOI: 10.5552/drind.2014.1256

Lesar, B., and Humar, M. (2011). "Use of wax emulsion for improvement of wood durability and sorption properties," European Journal of Wood and Wood Products 69(2), 231-238. DOI: 10.1007/s00107-010-0425-y

Li, R., Chen, J., and Wang, X. (2020). "Prediction of the color variation of Moso bamboo during $\mathrm{CO}_{2}$ laser thermal modification," BioResources 15(3), 5049-5057. DOI: 10.15376/biores.15.3.5049-5057

Lunguleasa, A., Ayrilmis, N., Spirchez, C., and Özdemir, F. (2018). "Investigation of the effects of heat treatment applied to beech plywood," Drvna Industrija 69(4), 349-355. DOI: $10.5552 /$ drind.2018.1768

Majka, J., Zborowska, M., Fejter, M., Waliszewska, B., and Olek, W. (2018). "Dimensional stability and hygroscopic properties of PEG treated irregularly degraded waterlogged Scots pine wood," Journal of Cultural Heritage 31, 133-140. DOI: 10.1016/j.culher.2017.12.002

Mitani, A., and Barboutis, I. (2014). "Changes caused by heat treatment in color and dimensional stability of beech (Fagus sylvatica L.) wood," Drvna Industrija 65(3), 225-232. DOI: $10.5552 /$ drind.2014.1250

Pelit, H. (2016). "Color characteristics of densified and thermally post-treated beach and pine woods," Mugla Journal of Science and Technology 2(2), 187-192.

Pelit, H., and Yalçin, M. (2017). "Resistance of mechanically densified and thermally post-treated pine sapwood to wood decay fungi," Journal of Wood Science 63, 514522. DOI: $10.1007 / \mathrm{s} 10086-017-1641-4$

Rapp, A. O., and Sailer, M. (2001). "Oil-heat-treatment of wood - Process and properties," Drvna Industrija 52(2), 63-70.

Reinprecht, L. (2016). Wood Deterioration, Protection and Maintenance, John Wiley \& Sons, Ltd., Chichester, UK.

Reinprecht, L., and Repák, M. (2019). "The impact of paraffin-thermal modification of beech wood on its biological, physical and mechanical properties," Forests 10(12/1102), 1-14. DOI: 10.3390/f10121102 
Reinprecht, L., Tiralová, Z., and Lakomčíková, J. (2007). 'Protiplesňová odolnost' bukových a borovicových OHT-termodriev [Mould-resistance of the beech and pine OHT-thermowoods]," in: Drevoznehodnocujúce Huby 2007, Mendelova zemědělská a lesnická univerzita v Brně, Brno, Czech Republic, pp. 16-22. ISBN 978-80-7175$105-0$

Reinprecht, L., and Vidholdová, Z. (2008). "Mould resistance, water resistance and mechanical properties of OHT-thermowoods," in: Sustainability Through New Technologies for Enhanced Wood Durability: Socio-economic Perspectives of Treated Wood for the Common European Market, Final Conference Proceedings of COST E37, Bordeaux, France, pp. 159-165.

Reinprecht, L., and Vidholdová, Z. (2011). Termodrevo [Thermowood], ŠMÍRA-PRINT s.r.o., Ostrava, Czech Republic, 89 p. ISBN 978-8087427-05-7

Repák, M., and Reinprecht, L. (2020). "Physico-mechanical properties of thermally modified beech wood affected by its pre-treatment with polyethylene glycol," Acta Facultatis Xylologia Zvolen 62(1), 67-78. DOI: 10.17423/afx.2020.62.1.06

Repák, M., and Reinprecht, L. (2021). "The color of beech wood modified in air, paraffin or polyethylene glycol, and after following weathering in Xenotest," Acta Facultatis Xylologiae Zvolen 63(2), 55-71. DOI: 10.17423/afx.2021.63.2.05

Sailer, M., Rapp, A., and Leithoff, A. (2000). "Improved resistance of Scots pine and spruce by application of an oil-heat treatment," in: The International Research Group on Wood Preservation, Stockholm, Sweden, IRG/WP 00-40162

Sandberg, D., Kutnar, A., Karlsson, O., and Jones, D. (2021). Wood Modification Technologies - Principles, Sustainability, and the Need for Innovation, CRC Press, Taylor \& Francis Group, Boca Raton, Florida, USA.

Sehlstedt-Persson, M. (2003). "Colour responses to heat-treatment of extractives and sap from Pine and Spruce," in: $8^{\text {th }}$ International IUFRO Wood Drying Conference, Brasov, Romania, pp. 459-464.

Sundqvist, B., and Morén, T. (2002). "The influence of wood polymers and extractives on wood colour induced by hydrothermal treatment," Holz als Roh- und Werkstoff 60(5), 375-376. DOI: 10.1007/s00107-002-0320-2

Scholz, G., Krause, A., and Militz, H. (2009). "Capillary water uptake and mechanical properties of wax soaked Scots pine," in: Proceedings of the European Conference on Wood Modification, Goettingen, Germany, pp. 209-212.

Scholz, G., Militz, H., Gascón-Garrido, P., Ibiza-Palacios, M. S., Oliver-Villanueva, J. V., Peters, B. C., and Fitzgerald, C. J. (2010). "Improved termite resistance of wood by wax impregnation," International Biodeterioration \& Biodegradation 64(8), 688693. DOI: 10.1016/j.ibiod.2010.05.012

Srinivas, K., and Pandley, K. K. (2012). "Effect of heat treatment on color changes, dimensional stability, and mechanical properties of wood," Journal of Wood Chemistry and Technology 32(4), 304-316. DOI: 10.1080/02773813.2012.674170

STN 490104 (1987). "Skúšky vlastností rasteného dreva. Metóda zist’ovania nasiakavosti a navlhavosti [Tests of native wood properties. Method of water absorptivity and hygroscopic determining]," The Slovak Office of Standards, Metrology and Testing, Bratislava, Slovakia.

Tarkow, H., Feist, W., and Southerland, C. (1966). "Interaction of wood with polymeric materials. Penetration versus molecular size," Forest Products Journal 16(10), 61-65.

Tjeerdsma, B. F., Boonstra, M., Pizzi, A., Tekely, P., and Militz, H. (1998).

"Characterisation of the thermally modified wood: Molecular reasons for wood 
performance improvement," Holz als Roh-und Werkstof 56(3), 149-153. DOI: $10.1007 / \mathrm{s} 001070050287$

Tjeerdsma, B. F., Stevens, M., Militz, H., and Van Acker, J. (2002). "Effect of process conditions on moisture content and decay resistance of hydrothermally treated wood," Holzforschung und Holzverwertung 54(5), 94-99.

Tjeerdsma, B. F., Swager, P., Horstman, B. J., Holleboom, B. W., Homan, W. J. (2005). "Process development of treatment of wood with modified hot oil," in: European Conference on Wood Modification 2005, Gottingen, Germany, pp. 186-197

Toker, H., Baysal, E., Turkoglu, T., Kart, S., Sen, F., and Peker, H. (2016). "Surface characteristics of oriental beech and Scots pine woods heat-treated above $200{ }^{\circ} \mathrm{C}$," Wood Research 61(1), 43-54.

Tümen, İ., Aydemir, D., Gündüz, G., Üner, B., and Çetin, H. (2010). "Changes in the chemical structure of thermally treated wood," BioResources 5(3), 1936-1944.

Unger, A., Schniewind, A. P., and Unger, W. (2001). Conservation of Wood Artefacts, Springer-Verlag GmbH, Berlin-Heidelberg, Germany.

Van Acker, J., Stevens, M., Carey, J., Sierra-Alvarez, R., Militz, H., Le Bayon, I., Kleist, G., and Peek, R. D. (2003). "Biological durability of wood in relation to end-use," Holz als Roh- und Werkstoff 61(1), 35-45. DOI: 10.1007/s00107-002-0351-8

Vidholdová, Z., Reinprecht, L., and Igaz, R. (2017). "The impact of laser surface modification of beech wood on its color and occurrence of molds," BioResources 12(2): 4177-4186. DOI: 10.15376/biores.12.2.4177-4186

Wang, J. Y., and Cooper, P. A. (2005). "Effect of oil type, temperature and time on moisture properties of hot oil-treated wood," Holz als Roh- und Werkstoff 63(6), 417422. DOI: $10.1007 / \mathrm{s} 00107-005-0033-4$

Westin, M., Conti, E., Creemers, J., Flate, P. O., Gellerich, A., Irbe, I., Klamer, M., Mazela, B., Melcher, E., Moller, R., et al. (2013). "Report on COST E37 Round Robin Test - Comparison of results from laboratory and field tests," International Research Group on Wood Protection, Stockholm, Sweden, IRG/WP 13-20535, 12 pp.

Welzbacher, C., and Rapp, O. (2002). "Comparison of thermally modified wood originating from four industrial scale processes - durability," International Research Group on Wood Preservation, Stockholm, Sweden, IRG/WP 02-40229, 13 pp.

Wikberg, H., and Maunu, S. (2004). "Characterisation of thermally modified hard- and softwoods by ${ }^{13}$ C CPMAS NMR," Carbohydrate Polymers 58(4), 461-466. DOI: 10.1016/j.carbpol.2004.08.008

Yilgör, N., and Kartal, S. N. (2010). "Heat modification of wood: Chemical properties and resistance to mold and decay fungi," Forest Products Journal 60(4), 357-361. DOI: 10.1016/j.carbpol.2004.08.008

Zaman, A., Alen, R., and Kotilainen, R. (2000). "Thermal behaviour of Scots pine (Pinus sylvestris) and silver birch (Betula pendula) at 200-230 degrees C," Wood and Fiber Science 32(2), 138-143.

Article submitted: August 18, 2021; Peer review completed: September 28, 2021; Revised version received and accepted: October 15, 2021; Published: December 6, 2021. DOI: 10.15376/biores.17.1.652-672 